\title{
The evolution of anti-circumvention law
}

\author{
Ian Brown \\ E-mail: I.Brown@cs.ucl.ac.uk \\ Department of Computer Science, \\ UCL, Gower Street, \\ London WC1E 6BT
}

Countries around the world have since 1996 updated copyright laws to prohibit the circumvention of "Technological Protection Measures," technologies that restrict the use of copyright works with the aim of reducing infringement and enforcing contractual restrictions. This article traces the legislative and treaty history that lies behind these new legal provisions, and examines their interaction with a wide range of other areas of law: from international exhaustion of rights, through competition law, anti-discrimination measures, regulation of computer security research, constitutional rights to freedom of expression and privacy, and consumer protection measures. The article finds that anti-circumvention law as promoted by United

States trade policy has interfered with public policy objectives in all of these areas.

It picks out key themes from the free trade agreements, legislation and jurisprudence of the World Trade Organisation, World Intellectual Property

Organisation, United States, European Union member states, and South American, Asian and Australasian nations. There is now a significant movement in treaty negotiations and in legislatures to reduce the scope of anti-circumvention provisions to ensure their compatibility with other important policy objectives.

\section{Introduction}

The introduction of "anti-circumvention" rules has caused the most significant change in global copyright laws and treaties for decades. The Technological Protection Measures (TPMs) protected by these rules are techniques such as encryption (the scrambling of copyrighted works so they can only be read by licensed users and devices), watermarking (the embedding of information on copyright holders, restrictions on the use of works and the identities of licensed users) and copy restriction that all enforce conditions upon the users of digital works. These techniques have been given legal protection under recent World Intellectual Property Organisation (WIPO) treaties, and it is now illegal in many signatory states for users to circumvent TPMs even for the purpose of exercising legitimate exemptions in copyright law. ${ }^{1}$

Where did these legal provisions originate? What caused such a significant evolution in the international copyright system? What are the consequences for other areas of law? This paper looks at the evolution of anti-circumvention provisions, and how they are beginning to interact with a wide range of other public policy issues - touching areas as diverse as freedom of expression, privacy, competition law, academic research and consumer protection.

The paper is not an exhaustive survey, but identifies key themes from nations across five continents. It summarises the public policy process that began in the United Kingdom and United States, moved to WIPO, and from there continued to play out in 
the national legal systems of the states around the world that became party to the resulting treaties. It also looks at key differences in how anti-circumvention provisions have been implemented in national law.

While interaction with national law has limited the wide scope of the WIPO obligations, the United States is still pushing similar provisions in other international instruments. This policy evolution is continuing to have a significant impact, not just on copyright law, but on the foundations upon which the global information society of the $21^{\text {st }}$ century is being built.

\section{Provisions in international instruments}

\section{Legislative pre-history}

Legal restrictions were applied during the 1980s in the US against the supply of devices that circumvented specific TPMs such as satellite cable encryption systems ${ }^{2}$ or serial copyright management systems, ${ }^{3}$ which restrict copies of digital audio. A similar restriction appeared in the North American Free Trade Agreement. ${ }^{4}$ The European Union also restricted the supply or commercial possession of "means" of circumvention of TPMs applied to software:

Article 7 Special measures of protection

1. Without prejudice to the provisions of Articles 4, 5 and 6, Member States shall provide, in accordance with their national legislation, appropriate remedies against a person committing any of the acts listed in subparagraphs $(a),(b)$ and (c) below:

(c) any act of putting into circulation, or the possession for commercial purposes of, any means the sole intended purpose of which is to facilitate the unauthorized removal or circumvention of any technical device which may have been applied to protect a computer program. ${ }^{5}$

A more general ban on the supply of devices that could circumvent copy-protection applied to copyright works came in the UK's Copyright, Designs and Patents Act 1988. In one respect, this went further than later treaties and legislation, by banning even the publication of information on how to circumvent TPMs:

(2) The person issuing the copies to the public has the same rights against a person who, knowing or having reason to believe that it will be used to make infringing copies-

(a) makes, imports, sells or lets for hire, offers or exposes for sale or hire, or advertises for sale or hire, any device or means specifically designed or adapted to circumvent the form of copy-protection employed, or

(b) publishes information intended to enable or assist persons to circumvent that form of copy-protection,

as a copyright owner has in respect of an infringement of copyright. ${ }^{6}$

The UK law however did not lead to the inclusion of similar provisions in other states' copyright laws. Interestingly the restriction on the publication of information 
was limited to TPMs applied to software when the UK implemented the EU Copyright Directive in $2003 .^{7}$

\section{The original WIPO drafts}

The World Intellectual Property Organisation first became interested in Technological Protection Measures (as they came to be known) during the drafting of their model provisions on copyright law in 1989. WIPO initially proposed that member states make mandatory the inclusion of TPMs in devices that processed copyright works:

Obligations Concerning Equipment: Protection against Uses Conflicting with a Normal Exploitation of Works

(1) If equipment might normally be used for reproduction of works in a manner that, if not authorized by the authors concerned, would conflict with a normal exploitation of such works, the manufacture, importation or sale of such equipment shall be prohibited ... unless such equipment is made to conform to technical specifications which prevent its use in such a manner. ${ }^{8}$

Similar provisions persisted through discussions on new protection for phonogram producers. However, concerns about their impact on competition and innovation led to more focussed anti-circumvention-device provisions modelled on those contained in the UK Copyright, Designs and Patents Act 1988. ${ }^{9}$

\section{The US National Information Infrastructure White Paper}

The most significant input into the process that resulted in the WIPO Internet treaties emerged out of a report from President Clinton's Task Force on the National Information Infrastructure (NII). Their Intellectual Property Working Group, chaired by ex-copyright lobbyist and US Commissioner of Patents and Trademarks Bruce Lehman, spent two years producing a "White Paper" on "Intellectual Property and the National Information Infrastructure" that was published in September $1995 .{ }^{10}$ This noted that "content providers must be confident that the systems developed to distribute these works will be secure and that works placed on these systems will remain authentic and unaltered. If content providers cannot be assured that they will be able to realize a commercial gain from the sale and use of their products using the NII, they will have little incentive to use it." (p.177). Therefore:

the Working Group recommends that the Copyright Act be amended to include a new Chapter 12, which would include a provision to prohibit the importation, manufacture or distribution of any device, product or component incorporated into a device or product, or the provision of any service, the primary purpose or effect of which is to avoid, bypass, remove, deactivate, or otherwise circumvent, without authority of the copyright owner or the law, any process, treatment, mechanism or system which prevents or inhibits the violation of any of the exclusive rights under Section 106. The provision will not eliminate the risk that protection systems will be defeated, but it will reduce it. (p.230)

The NII proposals were controversial, to say the least. While popular with copyright owners, the report "was heavily criticized by other groups, including telephone companies, ISPs, computer companies, universities, libraries, and scientific organizations, as to its interpretation of existing law and as to its legislative proposals."11 
While some of the report recommended balance in the design and protection of TPMs, these sections seem to be largely absent in the resulting legislation. "Such security measures must be carefully designed and implemented to ensure that they not only effectively protect the owner's interests in the works but also do not unduly burden use of the work by consumers or compromise their privacy." (p.191).

With unintended irony, the report also recommends that standards bodies be wary of TPMs that are encumbered with intellectual property rights, and that competition law may be necessary to regulate the exploitation of such intellectual property in de facto standards (p.200)

\section{The WIPO Copyright and Performances and Phonograms Treaties}

Draft legislation was quickly introduced in the US House of Representatives and Senate to implement the recommendations of the NII White Paper (S. 1284 and HR. 2441 of December 1995). However, an outpouring of public criticism led by technology and telecommunications companies, libraries and civil liberties groups prevented these drafts from making any progress in Congress. ${ }^{12,13}$

Commissioner Lehman, who also headed the US delegation to the WIPO Standing Committee on Copyright and Related Rights (SCCR), saw another route to have the NII recommendations implemented. "It appeared that Administration officials might be able to get in Geneva what they could not get from the U.S. Congress, for the draft treaties published by WIPO in late August 1996 contained language that, if adopted without amendment at the diplomatic conference in December, would have substantially implemented the U.S. digital agenda, albeit with some European gloss." 14 Congress would then have been constrained by this treaty in any amendments made to US copyright law. ${ }^{15}$

This approach did not proceed smoothly. Senator Orrin Hatch wrote to Lehman that: "Surely you will not want to be in the position of negotiating final language on a treaty that as yet commands no clear support in the full Senate and which may not ultimately be ratified. Congress will not wish to be in the position of having its hands tied by international developments on the basis of proposed legislation that has stalled precisely because it contains so many unresolved issues." 16

The US submission to the SCCR on the treaties had used anti-circumvention language almost identical to that of the White Paper's draft Copyright Act amendments. One key difference was the removal of the requirement that circumvention be permitted if done by "authority of... the law," so removing the explicit protection of circumvention done for legitimate purposes under copyright exemptions. The SCCR however was keen on this protection, and added a further requirement that prohibitions only be introduced against device manufacturers or service providers "knowing or having reasonable grounds to know" that a device or service would be used for purposes not authorised by copyright holder.

Even after this and other amendments, many SCCR members were unhappy about much of this language. In the end the SCCR settled for a more neutral provision suggested by South Africa:

Contracting parties shall provide adequate legal protection and effective legal remedies against the circumvention of effective technological measures that are used by authors in connection with the exercise of their rights under this treaty 
or the Berne Convention and that restrict acts, in respect of their works, which are not authorized by the authors concerned or by the law.

This became article 11 of the final WIPO Copyright Treaty ${ }^{17}$ (WCT) and mutatis mutandis, article 18 of the Performances and Phonograms Treaty ${ }^{18}$ (WPPT). These treaties came into force on 6 March 2002 and 20 May 2002 respectively.

This language left room for contracting states to experiment with anti-circumvention law, given its novelty on the international stage. However, articles 11 and 18 have two key weaknesses. They state that national provisions must be "adequate" and "effective" but neither these terms nor "effective technological measures" are defined. ${ }^{19}$

More importantly, they can be seen to require contracting parties to ban the act of circumvention as well as devices or services that enable it. A WIPO 2003 study commented: "Although the language is ambiguous, it does lend itself to the interpretation that it focuses more on the act of circumvention rather than on the devices, as had the Basic Proposal." 20

This has caused much of the resulting legal uncertainty and interaction with other law as its effect extends to the billion or more users affected by technical protection technologies rather than a much smaller number of equipment manufacturers and service providers. This has an unfortunate similarity with the manner in which copyright has become so much more controversial and influential over the course of the twentieth century as it has moved from regulating a small number of publishing companies to governing hundreds of millions of photocopier users, home tapers, remix artists and website authors. ${ }^{21}$

\section{Intellectual property chapters in recent US Free-Trade Agreements}

Since its partial defeat at WIPO, the US has negotiated explicit anti-circumvention provisions in bilateral free-trade agreements with Jordan (merely repeating and clarifying WCT article 11), ${ }^{22}$ Singapore, ${ }^{23}$ Chile (specifically allowing circumvention under authority of law i.e. fair use), ${ }^{24}$ Bahrain, ${ }^{25}$ Australia ${ }^{26}$ and Morocco. ${ }^{27}$ These provisions are also contained in the multilateral Central America-Dominican Republic-United States Free Trade Agreement (CAFTA) ${ }^{28}$ and the Free-Trade Area of the Americas (FTAA) draft treaties. ${ }^{29}$

The US agreement with Jordan merely sets out that in relation to WCT article 11:

each Party shall prohibit civilly and criminally the manufacture, importation or circulation of any technology, device, service or part thereof, that is designed, produced, performed or marketed for engaging in such prohibited conduct, or that has only a limited commercially significant purpose or use other than enabling or facilitating such conduct.

However, the later agreements go into far more detail, and prohibit circumvention as well as the supply of circumvention devices. In the Australian agreement the equivalent to WCT article 11 "goes on for two and a half single spaced, typed pages. It defines what technological measures are, what acts relating to them are proscribed, what exceptions may be provided, and even when and how new exceptions can be created, and what criteria we can apply in creating them." ${ }^{30}$ The language in the other bilateral agreements as well as CAFTA is extremely similar. 
These agreements have caused further concern in Congress that the administration was again engaging in "policy laundering," by creating through treaties new copyright obligations that could not have been passed domestically. Representatives Lofgren and Boucher wrote to the Secretary of Commerce to enquire about the effect of these agreements: "Congresswoman Lofgren raised this question with United States Trade Representative staff. She specifically asked whether adoption of H.R. 1066 or H.R. 107, two bills currently in Congress that would amend the DMCA, would result in a breach of our treaty obligations if the FTA's are adopted. She was advised orally that the treaties would be breached by the enactment of these bills into law. Since that time, various interested persons in the technology sector of our economy have indicated their hope that these treaties would permit the Congress to amend the DMCA." 31

The IP chapter of the FTAA drafts has caused considerable controversy ${ }^{32}$ and is the only recent treaty language where the US has not yet been able to achieve its objectives on anti-circumvention provisions. One negotiating option in the "Copyright and Related Rights" section of the latest draft of the agreement merely restates WCT article 11 and WPPT article 18 along with protection for broadcasters, with the added proviso that "technological measures shall not affect the exercise of the exceptions or limitations established in national legislation." The second option uses similar text to the Digital Millennium Copyright Act to prohibit acts of circumvention and the supply of circumvention devices, but omits the explicit further requirements and exceptions from recent bilateral agreements.

Other optional text in the "Enforcement" section of the draft severely limits the scope of the provisions, and reflects an alternative vision of how anti-circumvention restrictions might look, being limited to commercial activities and devices that restrict reproduction:

6.1. Each Party shall provide adequate legal protection and effective legal remedies against any of the following acts, when undertaken for economic gain:
b) The alteration, removal or the rendering inoperable, in any way, of technical devices designed to impair or limit reproduction of a work or protected production;

The FTAA negotiations have stalled since the last ministerial meeting held during November 2003 in Miami. One of the sticking points at that meeting was the demand from Mercosur (Brazil, Argentina, Uruguay and Paraguay) that IP be excluded from the process. Even a proposal for an "FTAA Light," which covered a far smaller set of issues around trade liberalisation, was not able to command consensus.

The US has recently concentrated on the bilateral and more limited CAFTA multilateral agreements described earlier, as well as on negotiations with the Andean Community (Peru, Colombia and Ecuador) and Panama. This is a reprise of US negotiating strategy during the process that lead to the World Trade Organisation's Agreements on Trade-Related Aspects of Intellectual Property Rights (TRIPS), when state opponents of a strong TRIPS agreement were slowly brought on-side through a combination of the threat of trade sanctions and the conclusion of individual bilateral agreements. $^{33}$ 


\section{Recent multilateral drafting: the WIPO Broadcasting Treaty}

Argentina, Egypt, the European Community and its Member States, Honduras, Japan, Kenya, Singapore, Switzerland, the United States of America and Uruguay have all proposed that a new WIPO treaty on the protection of broadcasting organisations should include anti-circumvention provisions. Their proposal would include virtually identical text to the WPPT as article 16 of the draft treaty:

Contracting Parties shall provide adequate legal protection and effective legal remedies against the circumvention of effective technological measures that are used by broadcasting organizations in connection with the exercise of their rights under this Treaty and that restrict acts, in respect of their broadcasts, that are not authorized or are prohibited by the broadcasting organizations concerned or permitted by law. ${ }^{34}$

The inclusion of this article has been strongly disputed by Brazil and Chile. They are concerned that the treaty could have a wide impact on access to knowledge, particularly if it is extended to webcasting under US pressure- which could be interpreted as the transmission of any audio or video over the Internet.

\section{The TRIPS Council}

The Agreement on Trade Related Aspects of Intellectual Property Rights ${ }^{35}$ (TRIPS) included in the treaty that created the World Trade Organisation (WTO) was silent on the subject of Technological Protection Measures. The Uruguay trade round that led to the treaty began in 1986 and dragged on for many years, with major controversy over even the inclusion of a set of information monopoly requirements in a free-trade agreement. This controversy and the then-novelty of anti-circumvention provisions meant that they were not included within TRIPS.

The TRIPS Council, which oversees the agreement, has occasionally discussed the subject. Australia proposed in both $1999^{36}$ and $2000^{37}$ that the Council draft amendments to TRIPS that would incorporate the principles of the WCT and WPPT, under the fast-track procedure outlined in TRIPS article 71.2. However, the support of other Council members for action was not forthcoming, with the US commenting: "The Council should focus on how the TRIPS Agreement already provided such a sound basis and perhaps less so on what potential shortcomings there might be." 38

\section{Provisions in national and regional law}

The two most significant implementations so far of the WCT and WPPT have been the United States' Digital Millennium Copyright Act and the European Union's Copyright Directive. The former has acted as a template for other states, particularly through its impact on ensuing US free trade agreements. The latter has changed the direction of copyright law in the European Economic Area's 30+ member and aspiring member states, affecting another half a billion citizens.

\section{The United States Digital Millennium Copyright Act}

Given the final shape of the WCT's article 11, the US did not need to take any legislative action to meet the requirements of this part of the treaty. Existing US law meant that "copyright infringement accomplished through circumvention was already actionable as copyright infringement. In addition, courts imposed liability for knowing facilitation of copyright infringement on producers of devices that had no 
substantial noninfringing application." ${ }^{39}$ (The US free trade agreements negotiated after the WCT explicitly rule out reliance on this legislative approach to implementation, stating that "Each Party shall provide that a violation of the law implementing this paragraph is independent of any infringement that might occur under the Party's law on copyright and related rights." 40 ).

Nonetheless, substantive new anti-circumvention provisions were included in the legislation that came out of the NII's White Paper. After much argument and lobbying, the Digital Millennium Copyright Act (DMCA) of 1998 does not go as far as the White Paper in most areas such as explicit control over temporary reproductions. ${ }^{41}$ However, for anti-circumvention provisions this was the key moment that restrictions were extended to the act of circumventing access controls alongside bans on circumvention devices - regardless of whether copyright infringement resulted from the circumvention. While the DMCA tried to draw a distinction between access and copy controls, allowing the circumvention of the latter, in practice the difference has so far been moot. The legislation states:

$\$$ 1201. Circumvention of Copyright Protection Systems

(a) Violations regarding circumvention of technological measures.--

(A) No person shall circumvent a technological measure that effectively controls access to a work protected under this title.

(2) No person shall manufacture, import, offer to the public, provide, or otherwise traffic in any technology, product, service, device, component, or part thereof, that--

(A) is primarily designed or produced for the purpose of circumventing a technological measure that effectively controls access to a work protected under this title;

(B) has only limited commercially significant purpose or use other than to circumvent a technological measure that effectively controls access to a work protected under this title [17 U.S.C.A. S 1 et seq.]; or

$(C)$ is marketed by that person or another acting in concert with that person with that person's knowledge for use in circumventing a technological measure that effectively controls access to a work protected under this title. ${ }^{42}$

This was against the clear sense of Congress that the DMCA should not prohibit circumvention for the exercise of fair-use rights. "[A]n individual [should] not be able to circumvent in order to gain unauthorized access to a work, but [should] be able to do so in order to make fair use of a work which he or she has acquired lawfully." 43 Jessica Litman commented: "It seeks for the first time to impose liability on ordinary citizens for violation of provisions that they have no reason to suspect are part of the law, and to make non-commercial and noninfringing behaviour illegal on the theory that that will help to prevent piracy." 44 So far bills such as the Digital Media Consumers' Right Act $^{45}$ that would firmly reapply this sense have not progressed in Congress. ${ }^{46}$ 
The DMCA does include some limited exceptions to this broad anti-circumvention provision. Non-profit library, archives, or educational institutions may circumvent access controls to determine whether to acquire a copy of a copyrighted work. The provision "does not prohibit any lawfully authorized investigative, protective, information security, or intelligence activity of an officer, agent, or employee of the United States, a State, or a political subdivision of a State, or a person acting pursuant to a contract with the United States, a State, or a political subdivision of a State." Software controls may be circumvented for the purpose of creating interoperable software. Controls may also be circumvented for the purposes of encryption research, security testing, and the protection of personal information. Circumvention components or parts are also permitted in devices that restrict access by minors to information on the Internet ${ }^{47}$. These exceptions are repeated in the free trade agreements concluded by the US since 2003 .

The Librarian of Congress conducts a triennial rule-making procedure under s.1201(a)(1)(C) that may exempt specific classes of works from DMCA anticircumvention protection, when persons may be "adversely affected by virtue of such prohibition in their ability to make noninfringing uses of that particular class of works". The Librarian must consider:

(i) the availability for use of copyrighted works;

(ii) the availability for use of works for nonprofit archival, preservation, and educational purposes;

(iii) the impact that the prohibition on the circumvention of technological measures applied to copyrighted works has on criticism, comment, news reporting, teaching, scholarship, or research;

(iv) the effect of circumvention of technological measures on the market for or value of copyrighted works; and

(v) such other factors as the Librarian considers appropriate.

This procedure has been used to exempt several classes of works since the enactment of the DMCA, including eBooks that prevent access by the blind and lists of Web pages blocked by filtering software. ${ }^{48}$

\section{The European Union Copyright Directive and member state implementation}

The European Union Copyright Directive (EUCD) ${ }^{49}$ agreed in 2001 to implement the WIPO Internet treaties across the EU had to deal with great variation in existing member state copyright regimes, and is hence in many places extremely vague and open-ended.

Bernt Hugenholtz, chairman of the European Commission's Legal Advisory Board Intellectual Property Taskforce, has commented: "The intense pressure from the copyright industries and, particularly, from the United States (where the main right holders of the world reside), to finish the job as quickly as possible, has not allowed the Member States and their parliaments, or even the European Parliament, to adequately reflect upon the many questions put before them." ${ }^{, 5}$

The EUCD's restrictions on acts of circumvention and circumvention products and services are extremely similar to those of s.1201 of the DMCA: 
International Review of Law, Computers and Technology, forthcoming, 2006

\section{Article 6}

Obligations as to technological measures

1. Member States shall provide adequate legal protection against the circumvention of any effective technological measures, which the person concerned carries out in the knowledge, or with reasonable grounds to know, that he or she is pursuing that objective.

2. Member States shall provide adequate legal protection against the manufacture, import, distribution, sale, rental, advertisement for sale or rental, or possession for commercial purposes of devices, products or components or the provision of services which:

(a) are promoted, advertised or marketed for the purpose of circumvention of, or

(b) have only a limited commercially significant purpose or use other than to circumvent, or

(c) are primarily designed, produced, adapted or performed for the purpose of enabling or facilitating the circumvention of,

any effective technological measures.

The key difference with the DMCA comes in the definition of "effective technological measures":

3. For the purposes of this Directive, the expression "technological measures" means any technology, device or component that, in the normal course of its operation, is designed to prevent or restrict acts, in respect of works or other subject-matter, which are not authorised by the rightholder of any copyright or any right related to copyright as provided for by law or the sui generis right provided for in Chapter III of Directive 96/9/EC. Technological measures shall be deemed "effective" where the use of a protected work or other subject-matter is controlled by the rightholders through application of an access control or protection process, such as encryption, scrambling or other transformation of the work or other subject-matter or a copy control mechanism, which achieves the protection objective.

Circumvention of technologies that control acts or works not protected by copyright (such as DVD region codes, or protected public domain works) is therefore not restricted by the EUCD. ${ }^{51}$

Article 6(4) of the EUCD also requires that member states create an explicit mechanism to deal with the conflict between its anti-circumvention provisions and the exceptions to copyright law contained in article 5 of the directive. In most national implementations, this allows the user of a copyright work to appeal to an administrative tribunal if their fair dealing rights are restricted by a TPM:

4. Notwithstanding the legal protection provided for in paragraph 1, in the absence of voluntary measures taken by rightholders, including agreements between rightholders and other parties concerned, Member States shall take appropriate measures to ensure that rightholders make available to the beneficiary of an exception or limitation provided for in national law in accordance with Article 5(2)(a), (2)(c), (2)(d), (2)(e), (3)(a), (3)(b) or (3)(e) the means of benefiting from that exception or limitation, to the extent necessary to 
International Review of Law, Computers and Technology, forthcoming, 2006

benefit from that exception or limitation and where that beneficiary has legal access to the protected work or subject-matter concerned.

The provisions of the first and second subparagraphs shall not apply to works or other subject-matter made available to the public on agreed contractual terms in such a way that members of the public may access them from a place and at a time individually chosen by them.

The final subparagraph of article 6(4) removes the possibility for users of on-demand services that employ TPMs to exercise their fair dealing rights. This has proven one of the most difficult parts of the directive for member states to implement, in a way that does not bring the entire Internet within its ambit.

Finally, recital 48 of the directive specifies that the use of TPMs should not be required in electronic equipment, and that devices with a commercially significant non-circumvention purpose should not be restricted. This restates provisions from the DMCA and recent US free-trade agreements.

Recital 48 also requires that protection for TPMs should not hinder cryptography research. However, because of the obscure legal status of recitals, this requirement has only been given explicit effect in a small number of member states such as the UK. ${ }^{52}$

A survey of EU implementation of anti-circumvention provisions has found that there is widespread divergence between member states on the definitions of, restrictions on and penalties for circumvention. ${ }^{53}$ Most startlingly, some member states that joined the EU in 2004 have ignored the consensus amongst the old member states that circumvention for the purposes of exercising the exemptions in the Copyright Directive could not be allowed. Slovenia's implementation, for example, provides that:

(3) Limitations to rights pursuant to paragraph 1 shall be provided, under conditions laid down by this Act, including eventual payment of remuneration, in the following cases:

1. use for the benefit of people with a disability (Article 47a);

2. use for the purpose of teaching (Article 49);

3. private and other internal reproduction (Article 50);

4. performance of official proceedings (Article 56);

5. ephemeral recordings made by broadcasting organisations (Article 77(2)). ${ }^{54}$

\section{Jurisprudence and interaction with other law}

The US Digital Millennium Copyright Act has been in force since 2000, giving enough time for some legal precedent to develop and for follow-up legislation to be debated. Only now are the first cases being considered under the national implementations of the EU Copyright Directive, the first of which were enacted in 2003.

In the United States, some of the more egregious initial interpretations of the scope of the DMCA by lower courts have since been reversed by higher courts. However, there is yet to be any serious interaction between anti-circumvention provisions and other law such as consumer or privacy protections. Initial skirmishes between TPMs and 
free speech in the Corley linking case have not produced happy results for advocates of the First Amendment.

\section{Broad application to access control devices}

Some of the most controversial first DMCA cases covered technologies that seemed far removed from the protection of copyright works. Static Control, who produce printer cartridges that are compatible with Lexmark printers, were found to have circumvented a TPM put in place by Lexmark to prevent third-party manufacture of compatible cartridges. ${ }^{55}$ Skylink, who produce devices that enable authorised users to open remote garage locking mechanisms produced by Chamberlain, were accused of DMCA violation. ${ }^{56}$ Closer to the DMCA's stated purpose, Russian software that circumvented restrictions in Adobe's e-book reader was found to violate s.1201.

Higher courts have limited the scope of the DMCA in two rulings. In Lexmark $v$. Static Control, the Sixth Circuit Court of Appeal found that the "access" controls in s.1201(a) related to access to the expression of the software, not interaction with or use of the software. ${ }^{57}$ The Federal Circuit court found in Skylink that "(1) tools whose only significant uses are non-infringing cannot violate the DMCA, and (2) in construing the DMCA, courts should balance the desire of Congress to protect the flanks of copyright owners' rights, against users' rights such as fair use and interoperation." ${ }^{88}$ The jury in a case at the US District Court for the Northern District of California found that there had been no violation by ElcomSoft, whose intent was to facilitate personal rather than illicit copying. ${ }^{59,60}$

Ongoing DMCA cases include a suit from Tracfone, a prepaid wireless telephone service, against a competitor that unlocks subsidised mobile phone handsets, ${ }^{61}$ and an appeal to the full Federal Circuit Court of Appeals by hard disc manufacturer StorageTek against another company who had to circumvent a basic TPM in order to service StorageTek devices. StorageTek have also requested that the court overturn the previous ruling in favour of Skylink's garage door openers, with the support of a range of copyright owner associations including the recording industry and motion picture associations of America. ${ }^{62}$

The most significant precedent that has been set over the scope of the DMCA is Corley $^{63}$. This case was concerned with a hypertext link carried by 2600 magazine to software that circumvented DVD access controls. The Second Circuit Court of Appeals categorised persistent access control technologies such as CSS as access controls which are protected under the much wider scope of s.1201(a) rather than as copy controls, which under s.1201(b) may be circumvented for the exercise of fair use rights. $^{64}$

\section{Region control and parallel imports}

One of the major uses of TPMs has been to enforce price discrimination between markets such as the US and EU. DVDs and Playstation games both carry "region codes" that specify whether these discs should operate in players sold in North America, Europe, Japan, Australasia and other markets. TPMs prevent discs bought in one region from being used in a player bought in another region.

The enforcement of price discrimination is plainly not a right granted by the EU Copyright Directive. As Timothy Bell wrote: "The role of government is not to ensure that a private business's pricing strategy succeeds, and consumers who have not 
agreed to help enforce the DVD cartel's segmentation scheme are under no obligation to respect it.",65

However, there have been contrasting rulings on whether circumventing such TPMs violates the EU Copyright Directive. In Italy, a judge found that Sony's attempts to prevent the modification of Playstation consoles to play foreign games "is similar to the Fiat car company selling cars that forbid extra drivers to use the car, or that forbid the owner to drive outside the city borders", and should not succeed under the EUCD. ${ }^{66}$ But in the UK, the High Court held that the transient copy of a game which is made in the memory of Playstation as it is played is a reproduction that is protected under Art. 2 EUCD, and hence the modification of a TPM that allows foreign games to be played comes into the scope of anti-circumvention law ${ }^{67}$. This was despite extremely specific language in the UK implementation of the EUCD: "In this section, the reference to... protection of a work is to the prevention or restriction of acts that are not authorised by the copyright owner of that work and are restricted by copyright. ${ }^{, 68}$ A similar ruling was made in a case concerning the sale of Playstation TPM circumvention devices in Australia. ${ }^{69}$ But other jurisdictions such as Hong Kong are working to implement anti-circumvention provisions in a way that does not support market segmentation. ${ }^{70}$

\section{Disabled persons}

One of the most important exemptions in the EU Copyright Directive is to enable disabled persons to convert copyright works to accessible formats such as an audio or Braille version of a written work. The UK has implemented this exemption using primary legislation (s.1 Copyright (Visually Impaired Persons) Act 2002), which allows circumvention of TPMs by holding that an accessible copy of a work made by a visually impaired person does not infringe copyright in that work, and hence does not circumvent a mechanism applied to a copyright work.

This legislative mechanism is available to any EU member state that has implemented the Directive as intended, restricting anti-circumvention protection to TPMs applied to copyright works.

\section{Security research}

Both the DMCA and EUCD include a specific exemption for "encryption" or "cryptography" research. However, very little computer security research involves the design of new ciphers, particularly with the specific methodology of examining new ciphers contained in Technological Protection Mechanisms.

Of much wider interest is the design of secure systems that contain viruses, spyware and other malicious technologies. This has become particularly relevant to anticircumvention law due to the recent appearance of TPMs that rely on virus-like technology, such as the XCP system used on several CD releases from Sony-BMG.

Researchers are also interested in the effectiveness of digital watermarking, a Rights Management Information technology related to TPMs that also receives protection under the various TPM treaties and laws.

Because of the wording of the EUCD and DMCA exemptions, researchers that investigate technologies such as XCP and watermarks are on shaky legal ground in the EU and US. A research team led by Professor Edward Felten that found weaknesses in watermarks proposed for use in the Secure Digital Music Initiative 
format was threatened with legal action - as were the teams' employers, and the organisers and hosts of the conference where they planned to publish their work. ${ }^{71}$

Felten withdrew the paper but sought a declaratory judgment that publication of the research would not violate the DMCA. The court dismissed the suit for lack of standing, stating: "The plaintiffs liken themselves to modern Galileos persecuted by authorities. I fear that a more apt analogy would be to modern day Don Quixotes feeling threatened by windmills which they perceive as giants. There is no real controversy here., 72

Felten has continued research in this area, including on XCP. To ensure that another court is not given the opportunity to revisit the Don Quixote issue, he has asked the US Copyright Office to exempt from the DMCA anti-circumvention provisions compact discs protected by TPMs that compromise the security of personal computers:

Because of the narrow scope of the DMCA's research exemption, the security researchers who are best situated to discover and disclose serious threats to personal computers face uncertain liability for their activities. In their efforts to determine the security threats posed by these protection measures, these researchers are likely to disable or remove some portion or the entirety of the protection measure, and thus potentially run afoul of the DMCA. ${ }^{73}$

Implementations of the EUCD cryptography research exemption are even weaker. In part, this is because the exemption is contained in a Recital, not an Article, with a less certain legal status. Few EU members have therefore transposed the exemption into national law. The UK, which added the exemption to its second draft of legislation after lobbying by computer scientists, restricts the publication of the results of the research ${ }^{74}$ - which removes much of the incentive to undertake such research.

\section{Freedom of expression}

Restrictions on the distribution of anti-circumvention devices have been interpreted in the US to trump constitutional rights to freedom of expression. In the case of Universal v. Remeirdes, the court found that even links to code that circumvented the Content Scrambling System applied to DVDs violated the DMCA. This was despite an explicit clause (s.1201(c)(4)) protecting free speech: "Nothing in this section shall enlarge or diminish any rights of free speech or the press for activities using consumer electronics, telecommunications, or computing products." The court rejected a defence made under the First Amendment to the US Constitution on the grounds of the functional nature of the code and the impact it could have on the market for DVDs. Pamela Samuelson has commented that "all too often in recent years, when courts have perceived a conflict between intellectual property rights and free speech rights, property has trumped speech." 75

Interestingly, the movie industry has therefore achieved what the US government could not in regard to encryption software: legal precedent that functionality trumps the expressive nature and hence constitutional protection of computer code.

The UK has maintained Copyright, Designs and Patent Act 1988 provisions that ban the publication of information that could be used to circumvent TPMs that are applied to software. A court is yet to consider the compatibility of this ban with the European Convention on Human Rights' Article 10 provisions on freedom of expression. ${ }^{76}$ 


\section{Competition law}

The capability of TPMs to restrict interoperability and hence reduce competition has not passed right holders and technology companies by. Apple has threatened to use the DMCA to stop Real Networks producing media player software that is compatible with music downloaded from the iTunes Music Store. ${ }^{77}$ Apple's dominant position in this market has allowed it to refuse requests from the music industry to charge different prices for tracks sold via the service. ${ }^{78}$ So far, competition authorities have refused to intervene to prevent such anticompetitive behaviour.

The French government has introduced explicit provisions in its draft implementation of the EUCD to stop anti-circumvention law being used to prevent reverse engineering of software to allow compatible programs to be produced. The latest draft states: "The authorization of the rightholder shall not be required where reproduction of the code and translation of its form within the meaning of Article 4 (a) and (b) are indispensable to obtain the information necessary to achieve the interoperability of an independently created computer program with other programs". ${ }^{79}$ This backs up the provisions in the Software Directive that allow reverse engineering. ${ }^{80}$ However, the similar reverse engineering exemption in the DMCA (s.1201(f)) has so far not achieved this goal.

The resulting lack of competition in the market for media software and devices acts as a significant impediment to innovation. As Timothy Bell commented: "It hardly promotes progress to give a handful of companies the ability to tightly control how consumers use copyrighted content. Rather, progress is promoted in a technological marketplace of interoperable products, consumer choice, and fierce competition." 81 Some competition economists have suggested that TPMs, or even knowledge itself, be treated as an "essential facility" under competition law. ${ }^{82}$

\section{Consumer protection}

Consumer protection law is increasingly being seen as an avenue of redress against TPMs that restrict consumer rights. Basic protections against mis-selling and requirements that goods be fit for purpose have allowed consumers in the US and EU to return audio CDs protected by TPMs that prevent use in car stereos or personal computer players.

Legislation such as the UK Computer Misuse Act 1990 could cover TPMs that make an "unauthorised modification" to computer systems to "prevent or hinder access to any program or data held" or "impair the operation of any such program" without explicit user consent. ${ }^{83}$ Ed Felten has commented that: "These protection measures have created serious threats to the security of personal computers, private and public networks, and the Internet generally, forcing consumers to choose between lawfully accessing the CDs they purchase and risking a hostile takeover of their computers."

Actions are being taken against Sony-BMG for its use of the XCP and MediaMax TPMs by US state attorneys general under specific anti-spyware law. The Texas attorney-general commented: "SONY has engaged in a technological version of cloak and dagger deceit against consumers by hiding secret files on their computers. Consumers who purchased a SONY CD thought they were buying music. Instead, they received spyware that can damage a computer, subject it to viruses and expose the consumer to possible identity crime." 85 
Private actions have also been taken in the US. The Electronic Frontier Foundation recently settled a class action lawsuit against Sony, which claimed: "By including a flawed and overreaching computer program in over 20 million music CDs sold to the general public, including California residents, Sony BMG has created serious security, privacy and consumer protection problems that have damaged Plaintiffs and thousands of other Californians."

Requirements for explicit labelling of TPMs have been one immediate legislative response. Proposed legislation from US Representative Rick Boucher would require adequate labelling of digital music products that satisfies rules from the Federal Trade Commission. ${ }^{87}$

Consumer groups may also renew pressure on legislators to allow the circumvention of TPMs that do not facilitate the exercise of copyright exemptions. US

Representative Christopher Cox proposed a joint Congressional resolution that:

It is the sense of Congress that, with respect to all electronic media in United

States commerce, consumers who legally acquire copyrighted and noncopyrighted works should be free to use these works in non-commercial ways. The enumeration of rights in section 3, which shall be known as the Consumer Technology Bill of Rights, sets forth the rights of all Americans to personal control of information and entertainment content they have lawfully acquired and from which they do not intend to profit. ${ }^{88}$

\section{Privacy}

The ability of TPMs to collect data on the usage of protected content can have a direct impact on users' privacy. ${ }^{89}$ Records of consumer use of CDs and DVDs might be abused for marketing purposes, but more importantly the monitoring of citizens' access to news and political information has the potential to stifle democratic debate and "inhibit the expression of non-conformist opinions and preferences."

In some recent cases, TPMs have been widely used that do not provide even the most basic information to consumers about the information that is being gathered about them. Researchers found that the MediaMax software used by Sony-BMG "collects and transmits data about consumers despite statements in both the software EULA and SunnComm's website denying any such behaviour". ${ }^{91}$

The DMCA explicitly allows the circumvention of TPMs in order to prevent the gathering of personal data (s.1201(i)). In the EU, the Data Protection Directive (DPD) makes it illegal for companies to collect information about consumers without clear user consent, except where "the processing is necessary for the performance of a contract or for the establishment, exercise or defence of legal claims or for realising legitimate interests that outweigh the privacy interests at stake" ${ }^{\text {"92 }}$. The Copyright Directive explicitly does not override the DPD; article 9 states: "This Directive shall be without prejudice to provisions concerning in particular ... data protection and privacy".

The DPD provides European citizens with a range of other protections such as the requirement that the amount of personal information collected by companies is minimised and that the data is deleted once no longer required for the stated purposes. National implementations, particularly in Germany, already encourage the development of technology that is minimally intrusive. ${ }^{93}$ A similar requirement exists in Australian privacy law, which requires that: "Wherever it is lawful and practicable, 
individuals must have the option of not identifying themselves when entering transactions with an organisation." 94

Privacy protections are strengthened under article 8 DPD when they concern data about sensitive aspects of citizens' lives, such as political opinions, religious or philosophical beliefs and health or sex life. This data could certainly be gathered by TPMs that monitor access to content concerning these subjects, although the level of sensitivity will be determined by context. ${ }^{95}$

\section{Conclusion}

Anti-circumvention rules have caused a major change in international copyright norms, and been controversial throughout their negotiation and enactment into national law. Despite the flexibility of the WIPO Internet treaties, the US has continued to promote broad restrictions with narrow exemptions on circumvention acts and devices via free-trade agreements ${ }^{96}$, modelled on its own Digital Millennium Copyright Act as a specific implementation of the WIPO treaties. However, the draft WIPO broadcasting treaty and Free Trade Area of the Americas agreement are still using WCT-like language, which provides further evidence that US negotiating power is more constrained in these multilateral fora than in bilateral treaties. ${ }^{97}$ Some jurisdictions such as Brazil are trying to exclude these provisions altogether, or as in Canada at least wait until more data is available about the effect of TPMs and their circumvention on the market for copyright works. ${ }^{98}$

The relatively vague provisions of article 11 WCT and article 18 WPPT were felt by many user groups at the time to represent a victory against the more explicit provisions proposed by the US. However, by moving away from specific language on circumvention devices, they gave an opportunity to the US and EU to use the treaties to justify restrictions on circumvention acts. This has given a far wider scope to the provisions, and caused much of the controversy over fair use and fair dealing rights that have been constrained by TPMs.

The vague language of these articles has been replicated in many national laws, particularly via the EU Copyright Directive, leaving the definitions, scope and sanctions of anti-circumvention provisions all uncertain. ${ }^{99}$ Even clearly-written DMCA exemptions to enable interoperability and protect free speech seem to have confused courts.

TPMs are about to take a great leap forward in effectiveness through their inclusion in new "trusted computing" platforms (now being added as an underlying component of forthcoming releases of Windows and Intel processors, and in many other operating systems and chipsets). ${ }^{100}$ This may render the distinction between acts of circumvention and circumvention devices moot, as only the most skilled computer scientists will have the ability to circumvent these measures.

Without re-legalising circumvention devices, the only way to ensure consumers are able to use their fair use or fair dealing rights may be using strengthened EUCD article 6(4)-like provisions on the interaction between exceptions and TPMs. For example, TPMs might only receive anti-circumvention protection if they enable users to take advantage of fair dealing exceptions.

Proposed US legislation such as Representative Zoe Lofgren's Digital Choice and Freedom Act would allow circumvention where TPMs blocked the exercise of fair use rights, as well as the distribution of circumvention devices that would enable users to 
make use of this capability. ${ }^{101}$ Representative Rick Boucher's Digital Media Consumers' Rights Act would also allow the manufacture and distribution of circumvention devices that enable "significant non-infringing use of a copyrighted work", and strengthen the DMCA's "encryption research" exemption. ${ }^{102}$

Nonetheless, even researchers from software companies such as Microsoft concede that the most restrictive TPMs will not prevent protected files from being converted to unprotected media formats and shared over peer-to-peer networks. ${ }^{103}$ As Koelman observed:

If the protection of technological measures does not cure the problem it is supposed to solve, it could be argued that it should not be inserted. The difficult choice between the protection of the measures and maintaining the limits of copyright needs then not be made. ${ }^{104}$

Consumers have also shown they are extremely unhappy with TPMs that restrict previously common uses of products such as format-shifting music from CDs to PCs and digital music devices - with the latest embarrassment and recall by Sony-BMG of protected CDs only the most recent in a long line of examples. The Internet has made consumer discussion of and campaigning over TPMs much easier and hence potentially more damaging to companies that release works using them.

Without acceptance by rightholders of the balance that is required in copyright law, it is likely that anti-circumvention laws will be brought into further disrepute, with collateral damage to the public respect shown to copyright law in general. Neither governments nor rightholders should welcome this prospect.

In the US, the country that has driven the world-wide move towards anticircumvention law, there are now calls from unlikely quarters for the DMCA to be repealed. A recent Cato Institute paper concluded:

Fortunately, repeal of the DMCA would not lead to intellectual property anarchy. Prior to the DMCA's enactment, the courts had already been developing a body of law that strikes a sensible balance between innovation and the protection of intellectual property. That body of law protected competition, consumer choice, and the important principle of fair use without sacrificing the rights of copyright holders. ${ }^{105}$

A recognition of the problems of anti-circumvention law as so far implemented would enable courts and legislators to re-balance these provisions to ensure that all stakeholders can participate equitably in the information society of the coming century.

\section{Acknowledgements}

The author would like to thank Urs Gasser, Gwen Hinze, Pamela Samuelson and particularly Nicholas Bohm for their helpful comments on this research.

\footnotetext{
$1 \quad$ Lawrence Lessig Code and other laws of cyberspace New York: Perseus Books, 1999.

47 U.S.C. $\$ 605(\mathrm{e})(4)$ (1988).

17 U.S.C. $\$ 1002(\mathrm{c})$ (Supp. V 1993).

NAFTA, H.R. Doc. No. 159, 103d Cong., 1st Sess. art. 1707(a) (1993).

Council Directive 91/250/EEC of 14 May 1991 on the legal protection of computer programs, O J L 122, 17/05/91 p. 42. Available from http://europa.eu.int/ISPO/legal/en/ipr/software/software.html UK Copyright, Designs and Patents Act 1988 s.296. Available from http://www.opsi.gov.uk/acts/acts1988/Ukpga_19880048_en_21.htm\#mdiv296
} 
International Review of Law, Computers and Technology, forthcoming, 2006

$7 \quad$ UK Copyright and Related Rights Regulations 2003 s.296ZA. Available from http://www.opsi.gov.uk/si/si2003/20032498.htm\#24

8 WIPO document CE/MPC/I/2-II

$9 \quad$ Mihály Ficsor The Law of Copyright and the Internet: The 1996 WIPO Treaties, their Interpretation and Implementation Oxford University Press (2002) pp.359-373

10 U. S. Working Group on Intellectual Property Rights of the National Information Infrastructure (NII) Task Force Intellectual Property and the National Information Infrastructure pp. 177-200, Sept. 1995. Available from http://www.uspto.gov/web/offices/com/doc/ipnii/

11 Pamela Samuelson and Hal Varian New Economy and Information Technology Policy: A review of information policy in the 1990s Economic Policy During the Clinton Administration, held at JFK School of Government, Harvard University, June 27-30, 2001 pp.17-18. Available from http://www.sims.berkeley.edu/ pam/papers/infopolicy

12 Pamela Samuelson Big Media Beaten Back Wired Magazine 5(3) March 1997. Available from http://www.wired.com/wired/5.03/netizen_pr.html

13 Jessica Litman Digital Copyright Amherst: Prometheus Books (2001) pp.125-130

14 Pamela Samuelson The U.S. Digital Agenda at WIPO 37 Va. J. Int'1 L. 369 (1997). Available from http://www.sims.berkeley.edu/ pam/courses/cyberlaw97/docs/wipo.pdf

$15 \quad$ Pamela Samuelson On Author's Rights in Cyberspace: Are New International Rules Needed? First Monday 1(4) October 1996. Available from http://www.firstmonday.dk/issues/issue4/samuelson/

16 Samuelson Big Media Beaten Back note 12

$17 \quad$ WIPO Copyright Treaty (1996). Available from

http://www.wipo.int/treaties/ip/wct/index.html

18 WIPO Performances and Phonograms Treaty (1996). Available from

http://www.wipo.int/treaties/ip/wppt/index.html

19 Urs Gasser and Michael Girsberger Transposing the Copyright Directive: Legal Protection of Technological Measures in EU-Member States Berkman Publication Series No. 2004-10, November 2004 p.6. Available from http://cyber.law.harvard.edu/media/files/eucd.pdf

20 Jeffrey P. Cunard, Keith Hill and Chris Barlas Current Developments in the Field of Digital Rights Management Prepared for World Intellectual Property Organization Standing Committee on Copyright and Related Rights Tenth Session, 2003, WIPO document SCCR/10/2 p.46. Available from http://www.wipo.int/documents/en/meetings/2003/sccr/doc/sccr_10_2_rev.doc

21 Lawrence Lessig The Future of Ideas: the fate of the commons in a connected world Random House (2001)

$22 \quad$ Article 4 (13), US-Jordan Free Trade Agreement concluded 24 October 2000, p.6. Available from http://www.ustr.gov/assets/Trade_Agreements/Bilateral/Jordan/asset_upload_file250_5112.pdf

23 Article 16.4 (7), US-Singapore Free Trade Agreement concluded 15 January 2003, pp.189191. Available from

http://www.ustr.gov/assets/Trade_Agreements/Bilateral/Singapore_FTA/Final_Texts/asset_upload_file 708_4036.pdf

$24 \quad$ Article 17.7 (5), US-Chile Free Trade Agreement concluded 6 June 2003, Chapter 17 pp.1518. Available from

http://www.ustr.gov/assets/Trade_Agreements/Bilateral/Chile_FTA/Final_Texts/asset_upload_file912_ 4011.pdf

$25 \quad$ Article 14.4 (7), US-Bahrain Free Trade Agreement concluded 14 September 2004, Chapter 14 pp.6-8. Available from

http://www.ustr.gov/assets/Trade_Agreements/Bilateral/Bahrain_FTA/final_texts/asset_upload_file211 6293.pdf

26 Article 17.4 (7), US-Australia Free Trade Agreement concluded 18 May 2004, Chapter 17 pp.7-10. Available from

http://www.ustr.gov/assets/Trade_Agreements/Bilateral/Australia_FTA/Final_Text/asset_upload_file4 69_5141.pdf Commentary at K. Weatherall Submission to Senate Select Committee on the Australia-

United States Free Trade Agreement Available from http://www.ipria.org/research/Submission_KWeatherall_SenateSelectCommittee2.pdf

$27 \quad$ Article 15.5(8), US-Morocco Free Trade Agreement concluded 15 June 2004, Chapter 15 pp.10-13. Available from http://www.ustr.gov/assets/Trade_Agreements/Bilateral/Morocco_FTA/FInal_Text/asset_upload_file7 97_3849.pdf

$28 \quad$ Article 15.5 (7) Central America-Dominican Republic-United States Free Trade Agreement concluded 5 August 2004 Chapter 15 pp.9-11. Available from 
http://www.ustr.gov/assets/Trade_Agreements/Bilateral/CAFTA/CAFTA-

DR_Final_Texts/asset_upload_file934_3935.pdf

Robin Gross Draft Intellectual Property Rights Chapter in the Free Trade Area of the Americas (FTAA) Treaty October 2003. Available from http://www.ipjustice.org/FTAA/IPJ_FTAA_White_Paper_r_1_2.html

$30 \quad$ K. Weatherall Locked In: Australia Gets a Bad Intellectual Property Deal Policy 20(4)

Summer 2004-05. Available from http://www.cis.org.au/policy/summer04-05/polsumm0405-3.pdf

$31 \quad$ Letter from US Representatives Lofgren and Boucher to the Secretary of Commerce, May 9

2003. Available at http://www.techlawjournal.com/cong108/ftas/20030509.asp

$32 \quad$ Free Trade Area of the Americas Draft Agreement Chapter XX Intellectual Property Rights

article B.2.c.22 and B.3.6 2003. Available from http://www.ftaa-

alca.org/FTAADraft03/ChapterXX_e.asp

33 Peter Drahos with John Braithwaite Information Feudalism London: Earthscan Publications, pp.108-149 (2002)

Second Revised Consolidated Text for a Treaty on the Protection of Broadcasting

Organizations WIPO SCCR/12/2 REV.2, 2 May 2005. Available from

http://www.wipo.int/edocs/mdocs/sccr/en/sccr_12/sccr_12_2_rev_2.doc

35 Trade-Related Aspects of Intellectual Property Rights Annex 1C, Marrakesh Agreement

Establishing the World Trade Organization (1994). Available from

http://www.wto.org/english/docs_e/legal_e/27-trips_01_e.htm

$36 \quad$ World Trade Organisation Minutes of meeting of TRIPS Council held 21-22 April 1999

(document IP/C/M/23) 2 June 1999. Available at http://docsonline.wto.org/gen_search.asp IP/C/M/23

$37 \quad$ World Trade Organisation Minutes of meeting of TRIPS Council held 27-30 November and 6

December 2000 (document IP/C/M/29) 6 March 2001. Available from

$\mathrm{http}: / /$ docsonline.wto.org/gen_search.asp

$38 \quad$ World Trade Organisation Minutes of meeting of TRIPS Council held 27-30 November and 6 December 2000 note 37

$39 \quad$ Litman Digital Copyright note 13 p.131

$40 \quad$ US-Singapore FTA note 23 article 16.4(7)(d) p. 190

$41 \quad$ Litman Digital Copyright note 13 p. 130

$42 \quad 17$ U.S.C. $\$ 1201$ (1998).

43 Committee of the Judiciary of the House of Representatives: House Report 105-551, Part I, Section-by Section Analysis of section 1201(a)(1).

$44 \quad$ Litman Digital Copyright note 13 p.145

45 H.R. 1201 Digital Media Consumers' Rights Act (March 2005). Available from

http://www.house.gov/boucher/docs/hr1201.pdf

${ }_{46}$ Richard Koman Lofgren, Boucher step up anti-DMCA efforts O'Reilly Policy Devcenter, 20

June 2003. Available from http://www.oreillynet.com/pub/wlg/3361

$47 \quad 17$ U.S.C. $\$ 1201(\mathrm{~d}-\mathrm{h})(1998)$.

$48 \quad$ Electronic Frontier Foundation Librarian of Congress Fails Public Interest in Copyright Regulation 28 October 2003. Available from http://www.eff.org/IP/DMCA/20031028_1201_pr.php

49 Directive 2001/29/EC of the European Parliament and of the Council of 22 May 2001 on the harmonisation of certain aspects of copyright and related rights in the information society O J L 167 , 22/06/2001 pp. $10-19$

$50 \quad$ P. Bernt Hugenholtz Why the Copyright Directive is Unimportant, and Possibly Invalid European Intellectual Property Review 2000-11, pp. 499-505. Available from http://www.ivir.nl/publications/hugenholtz/opinion-EIPR.html

${ }_{51}$ K.J. Koelman and N. Helberger Protection of Technological Measures in B. Hugenholtz, ed. Copyright and Electronic Commerce: Legal Aspects of Electronic Copyright Management London: Kluwer Academic Publishers (2000), p.171.

$52 \quad$ Ian Brown (Ed.) Implementing the European Union Copyright Directive London: FIPR, September 2003. Available from http://www.fipr.org/copyright/guide/

${ }_{53}$ Gasser and Girsberger Transposing the Copyright Directive: Legal Protection of Technological Measures in EU-Member States note 19

$54 \quad$ Article 166c of the Copyright and Related Rights Act of the Republic of Slovenia, as amended by the Act Amending the Copyright and Related Rights Act, Official Gazette RS No. 43/04. Unofficial English translation available from http://www.uil-sipo.si/Laws/ZASP_EN_04.pdf 55 Lexmark International Inc. v. Static Control Components, Inc., 253 F.Supp.2d 943 (E.D. Ky. 
56

57 Chamberlain Group, Inc. v. Skylink Technologies, Inc., 381 F.3d 1178 (Fed. Cir. 2004)

$57 \quad$ Judgment available from

http://www.eff.org/legal/cases/Lexmark_v_Static_Control/20041026_Ruling.pdf Commentary at http://www.freedom-to-tinker.com/?p=708

58 Judgment at http://www.corante.com/importance/archives/Chamberlain_v_Skylink.pdf Commentary at http://www.freedom-to-tinker.com/index.php?p=673

59 Richard Koman Boucher: DMCA-Fixing Bill "Will Win" O'Reilly Policy DevCenter 13 January 2003. Available from http://www.oreillynet.com/pub/a/policy/2003/01/13/boucher.html

$60 \quad$ Lisa M. Bowman Elcomsoft verdict: not guilty CNET News.com, 17 December 2002.

Available from http://news.com.com/2100-1023-978176.html

$61 \quad$ http://www.eff.org/deeplinks/archives/004414.php

62 Storage Technology v. Custom Hardware Engineering Available from

http://www.eff.org/deeplinks/archives/004123.php

${ }_{63}$ Universal City Studios v. Reimerdes, 111 F. Supp. 2 d 294 (S.D.N.Y. 2000), affirmed as

Universal City Studios, Inc. v. Corley, 273 F.3d 429 (2nd Cir. 2001)

64 Pamela Samuelson Digital Rights Management \{and, or, vs.\} the Law Communications of the ACM 46(4), April 2003 Available from

http://www.sims.berkeley.edu/ pam/papers/acm_v46_p41.pdf

65 Timothy B. Lee Circumventing Competition: The Perverse Consequences of the Digital

Millennium Copyright Act Cato Institute Policy Analysis no. 564, 21 March 2006. Available from http://www.cato.org/pub_display.php?pub_id=6025

66 Tribunale di Bolzano, 31 December 2003. Available from

http://www.ipjustice.org/123103playstationdecision.html with commentary at

http://www.ipjustice.org/media/release20040112_en.shtml

$67 \quad$ Laddie J [2004] EWHC 1738 (Ch) Available from http://www.hmcourtsservice.gov.uk/judgmentsfiles/j2680/sony-v-ball.htm

$68 \quad$ The Copyright and Related Rights Regulations 2003 note 7 s.296(Z)(F)(3)

69 Drew Cullen Sony wins Aussie mod-chip sales ban The Register, 31/7/203. Available from http://www.theregister.co.uk/2003/07/31/sony_wins_aussie_mod_chip/

Emma Barraclough Hong Kong backs copyright owners Manaing Intellectual Property 20 June 2005. Available from

http://www.managingip.com/default.asp?page=9\&PubID=198\&SID=519574\&ISS=16664\&LS=EMS4 6074

71 Letter from the Recording Industry Association of America to Professor Edward Felten, dated 9 April 2001. Available from http://www.theregister.co.uk/extra/sdmi-attack.htm

72 Felten v. RIAA (Transcript of Proceedings) (D NJ, 11/28/01). Available from http://www.eff.org/IP/DMCA/Felten_v_RIAA/20011128_hearing_transcript.html

$73 \quad$ Edward W. Felten and J. Alex Halderman Re: RM 2005-11-Exemption to Prohibition on

Circumvention of Copyright Protection Systems for Access Control Technologies 1 December 2005.

Available from http://www.freedom-to-tinker.com/doc/2005/dmcacomment.pdf with commentary at http://www.freedom-to-tinker.com/?p=938

$74 \quad$ The Copyright and Related Rights Regulations note 72003 s.296(Z)(A)(2)

75 Pamela Samuelson Anticircumvention Rules: Threat to Science Science 14 September 2001:

Vol. 293. no. 5537, pp. 2028 - 2031

$76 \quad$ Convention for the Protection of Human Rights and Fundamental Freedoms Council of

Europe, 4 November 1950. Available from http://conventions.coe.int/Treaty/en/Treaties/Html/005.htm

$77 \quad$ Eric Bangeman Apple responds to RealNetworks FairPlay hack ars technica, 29 July 2004.

Available from http://arstechnica.com/news.ars/post/20040729-4051.html

$78 \quad$ Bronfman Fires Back at Apple Red Herring 23 September 2005. Available from

http://www.redherring.com/Article.aspx?a=13702\&hed=Bronfman\%20Fires\%20Back\%20at\%20Apple

79 Council Directive 91/250/EEC of 14 May 1991 on the legal protection of computer programs, as amended by Directive 93/98/EEC 17/5/91 note 5, p. 42.

$80 \quad$ Council Directive 91/250/EEC of 14 May 1991 on the legal protection of computer programs as amended by Directive 93/98/EEC 17/5/91 note 5, articles 6 and 7.

$81 \quad$ Lee Circumventing Competition: The Perverse Consequences of the Digital

Millennium Copyright Act note 65 p.24

$82 \quad$ Cristiano Antonelli Technological Knowledge as an Essential Facility DIME Working Paper no. 3 March 2006. Available from http://ipr.dime-eu.org/files/active/0/IPR-WORKING-PAPER-

3_Antonelli.pdf 
International Review of Law, Computers and Technology, forthcoming, 2006

83 The Computer Misuse Act 1990 s.3. Available from

http://www.opsi.gov.uk/acts/acts1990/Ukpga_19900018_en_2.htm\#mdiv3

84 Felten and Halderman Re: RM 2005-11 - Exemption to Prohibition on Circumvention of Copyright Protection Systems for Access Control Technologies note 73

${ }_{85}$ Attorney General Abbott Brings First Enforcement Action In Nation Against Sony BMG For Spyware Violations 21 November 2005. Available from

http://www.oag.state.tx.us/oagNews/release.php?id=1266

86 Hull, et al v Sony BMG Music Entertainment, et al filed November 21, 2005 in the Superior

Court for Los Angeles County, California. Available from http://www.eff.org/IP/DRM/Sony-

BMG/sony_complaint.pdf

87 H.R. 1201 Digital Media Consumers' Rights Act note 45

88 H.J.R. 116 Consumer Technology Bill of Rights 7 October 2002. Available from http://thomas.loc.gov/cgi-bin/query/z?c107:H.J.RES.116:

${ }_{89}$ L.A. Bygrave Digital Rights Management and Privacy - Legal Aspects in the European

Union, pp.527-529, in E. Becker et al. Digital Rights Management-Technological, Economic, Legal and Political Aspects Heidelberg: Springer Verlag (2003) s.4. Available from

http://folk.uio.no/lee/publications/DRM_privacy.pdf

$90 \quad$ L.A. Bygrave The Technologisation of Copyright: Implications for Privacy and

Related Interests European Intellectual Property Review 2002 24(2) pp. 51-57

$91 \quad$ Felten and Halderman Re: RM 2005-11-Exemption to Prohibition on Circumvention of

Copyright Protection Systems for Access Control Technologies note 73

$92 \quad$ Bygrave The Technologisation of Copyright: Implications for Privacy and

Related Interests p. 60 note 90

93 Bygrave The Technologisation of Copyright: Implications for Privacy and

Related Interests p. 60 note 90

$94 \quad$ Graham Greenleaf IP, Phone Home: The Uneasy Relationship Between Copyright And

Privacy, Illustrated In The Laws Of Hong Kong And Australia Hong Kong Law Journal 32(1) 2002.

Available from http://www.hku.hk/law/hklj/32/gg.html

$95 \quad$ L. A. Bygrave Digital Rights Management and Privacy - Legal Aspects in the European

Union In E. Becker et al. (Eds.) Digital Rights Management Lecture Notes in Computer Science 2770, pp. 418-446, 2003. Available from http://folk.uio.no/lee/publications/DRM_privacy.pdf

Urs Gasser Legal Frameworks and Technological Protection of Digital Content:

Moving Forward Towards a Best Practice Model Draft document on file with author

$97 \quad$ Drahos Information Feudalism note 33 pp.108-149

$98 \quad$ Ian Kerr Technological Protection Measures: Part II - The Legal Protection of TPMs Report

for the Department of Canadian Heritage (2002). Available from http://www.pch.gc.ca/progs/ac-

ca/progs/pda-cpb/pubs/protectionII/tdm_e.cfm

$99 \quad$ Gasser and Girsberger Transposing the Copyright Directive: Legal Protection of

Technological Measures in EU-Member States note 53

$100 \quad$ Cunard, Hill and Barlas Current Developments in the Field of Digital Rights Management note 20 p. 13

$101 \quad$ Representative Zoe Lofgren Summary of the Digital Choice and Freedom Act of 2002

Available from http://www.house.gov/lofgren/news/2002/021002_summary.htm

$102 \quad$ H.R. 1201 Digital Media Consumers' Rights Act note 45

103 Peter Biddle, Paul England, Marcus Peinado, and Bryan Willman The Darknet and the Future of Content Distribution ACM Workshop on Digital Rights Management, 2002. Available from http://msl1.mit.edu/ESD10/docs/darknet5.pdf

${ }_{104}$ Kamiel J. Koelman The Protection of Technological Measures vs. the Copyright Limitations ALAI Congress, June 2001

$105 \quad$ Lee Circumventing Competition: The Perverse Consequences of the Digital

Millennium Copyright Act note 65 p. 1 